\title{
THE EFFECT OF ASSET STRUCTURE, PROFITABILITY, COMPANY SIZE, AND COMPANY GROWTH ON CAPITAL STRUCTURE (The Study of Manufacturing Companies Listed on the IDX for the Period 2013 - 2017)
}

\author{
Hilma Faza Ariyani¹, Irene Rini Demi Pangestuti², Susilo Toto Raharjo ${ }^{3}$ \\ ${ }^{1}$ Master of Management, Faculty of Economics and Business, Diponegoro University \\ ${ }^{2}$ Master of Management, Faculty of Economics and Business, Diponegoro University \\ ${ }_{3}^{3}$ Master of Management, Faculty of Economics and Business, Diponegoro University
}

\begin{abstract}
The purpose of this study was to determine and examine the effect of asset structure, profitability, firm size and company growth on the capital structure of manufacturing companies listed on the Indonesia Stock Exchange (IDX) in 2013 - 2017. The sampling method used was purposive sampling that was 52 companies in the criteria. Data obtained from the Financial Reports and Performance Reports published in the Indonesian Capital Market Directory (ICMD). The analytical tool that used is multiple regression. Hypothesis testing is done by the F test, $t$-test and determination coefficient. For the classical assumption, the test is done by normality test, autocorrelation test, multicollinearity test, and heteroscedasticity test. The analysis of asset structure has a positive effect on the capital structure and not significant to the capital structure, profitability has a negative and significant effect on the capital structure, the size of the company has a positive and significant effect on the capital structure, and the company's growth has a negative and significant effect on the capital structure.
\end{abstract}

Keywords: capital structure, assets structure, profitability, company size, company growth.

\section{INTRODUCTION}

The company's profit is the ultimate goal of every business process carried out by the Company. A manager who incidentally is a person who is responsible for the pace of a company, especially a financial manager who must be smart and careful in managing the company's finances. Starting from budgeting, using funds for investment, taking debt policy for additional funding sources. Sources of funds can be obtained from internal funding sources such as retention of profits, own capital, while funds sourced from external sources can be obtained from debt.

A capital structure according to Husnan (1998) is the value of the balance between corporate debt and equity. While the opinion of Weston and Copeland (1997) states that the proportion of debt and capital itself is called capital structure. This total debt consists of debt for a long period of time and also debt for a short period of time. Equity or own capital can be obtained

${ }^{1}$ Corresponding author, Email: hilmafaza1@gmail.com 
from retained earnings, and can also be obtained from the capital invested by the company.

According to the explanation put forward by Brigham and Houston (2011), the composition of capital must pay attention to asset structure, sales stability, leverage, growth rates, profitability, taxes, management policies and also the conditions within the company itself. These conditions must be taken into account by managers in making decisions. The factor of the market condition must also be taken into consideration, whether the business market is being sluggish or even on top. The company's ability is also a separate consideration, managers must be able to provide an assessment of the financial condition of the company, not to make policies taken beyond the ability limit.

According to Brigham and Houston (2011), there are three theories used in the capital structure, namely Modigliani-Miller (MM) theory, Signaling theory and TradeOff theory or Exchange Theory. Meanwhile, according to Husnan (2012), there is more to be used to underlie the capital structure, namely Pecking Order Theory. In this study for research conducted this time the author uses several theories that are used to support variables in the study and obtained from several previous studies, namely pecking order theory, signaling theory, and agency theory.

The comparison between a number of all foreign loans and sources of funds owned by themselves is called the capital structure. The composition of funding from a company in running its business. Debt to equity ratio (DER) is used for calculating the capital structure ratio in the research that the authors do which has a function to determine the amount of leverage compared to the total equity of the company. Total debt here is the amount between long-term debt and short-term debt. Own capital consists of the total initial capital of the company itself and retained earnings. The DER ratio shows that if the total debt held by the company is greater than the equity, the company will also increase its debt to cover its debt/loan.

According to Modigliani \& Miller (1958) said that there is no influence from the capital structure on firm value. But on condition that there is no tax imposed, brokerage fees are also not available, free from bankruptcy. The capital structure can be used as a marker of whether or not the financial condition of a company is healthy. The decision on funding to be used must look at various factors, both internal factors of the company and the external conditions of the company. It must also be seen that the company's long-term plan will move in which direction so that the decision on the composition of capital to be used can be optimal and on target.

The asset structure is the sum of all assets owned by the company in running its business. This asset structure consists of current assets and fixed assets. The results of fixed assets versus total assets in this study are asset structure. According to Brigham \& Houston (2006), a company that has these assets and assets is a guarantee of a loan, it is likely to use funds from debt. Because investors will easily believe by looking at the assets they have as collateral for funds issued by investors. Most companies that have businesses in the real estate sector will have high bargaining power against investors. According to Riyanto (2001), the ratio of current assets to fixed assets is the structure of assets.

Profitability is the profit generated by the company as a result of business activities. A company must be clever in using company assets to generate profits, this is called a profitability ratio. In general, 
what is used to measure solvency ratios is profit margins which are profit margins, then return on assets, namely the rate of return on assets and the last return on equity, the rate of return on capital. If a company earns a net profit on a sales target set at a certain level, that is what is regulated by profit margin. Management effectiveness can be indicated by a highprofit margin ratio.

Petronila and Muklasin (2003) in his research said that the company's performance in managing its business can be seen through its profitability. Like the company's profit which consists of two, namely operating profit and net profit. It can also be seen from the rate of return on investments made. Equity returns to shareholders can also be used as a measure of the level of profitability of the company.

According to Kusumawati (2005) in his research said the same thing that profitability is a measure to generate corporate profits. This profit is a profit target, meaning that it is profit in the future. If the profit target with the ability to generate profits is in line, then it can be said that the company is successful in running its operations. Here also will be discussed a little about the two types of profitability ratios which are related to sales and those related to investment. The margin obtained in gross profit and also in net income is the ratio related to sales. As for the return on assets, namely, return on assets (ROA) related to investment.

Profitability in this study is measured by using ROA which is the comparison value of the company's profits obtained on the number of assets owned. How effective a company is in using or empowering assets that it has to produce maximum company profits. The assets should be explored in a positive sense so that they can be useful for the company. There is no dictionary that these assets are left un-useful even to the point of stalling which in turn will burden the company due to high maintenance costs. Managers and shareholders must be able to rotate these assets in order to generate targeted profits. Or even some get dividends from company assets because these assets are leased to third parties. This rental consideration is because after being calculated it will be more profitable because it does not need to bear the cost of maintenance and so on.

The definition of company size or size is a condition that can be seen clearly by the number of assets owned by the company, then seen from the results of sales made, average sales and also the average of the total assets. The size of an asset can be described through net sales in the current year or current conditions and sales in previous years.

The size and size of the company will affect the capital composition/capital structure. The bigger a company will surely be more daring to make decisions on the use of loan funds with a large nominal. According to Indrajaya, Herlina, and Setiadi (2011) Company growth is an opportunity to make growth. Funds will be increasingly needed if a company is in a growing phase to finance its growth. A company that has a high chance will definitely continue to expand its business. Whereas the company's internal funds that are owned must be limited and lacking to be able to meet the needs of its business capital.

Company growth is the opportunity or opportunity that a company has to always improve performance by achieving its optimal growth rate. Funds will be increasingly needed if a company is in a growing phase. A lot of funds are needed to finance the development of the business. Whereas the company's internal funds that are owned must be limited and lacking to 
be able to meet the needs of its business capital.

The company's growth rate is a condition that shows how much the loan fund used by the company to fund its capital. Companies that in financing use equity, there will be agency costs there, namely the costs incurred because there is a reciprocal relationship between shareholders and the company manager. But these costs must have been calculated by the shareholders, with the agency costs incurred will be worth the income that will be received.

The size of the company is able or not to pay the entire liability to investors is called the Debt Equity Ratio (DER). And can also be obtained by comparing total debt to capital. Total debt consists of all debts incurred by the company. How big is the company's ability if the guarantee used for debt is the company's own capital.

\section{LITERATURE REVIEW}

In the article "The Cost of Capital, Corporation Finance and the Theory of Investment" by Modigliani \& Miller (1958) suggests that the value of a company's capital structure will continue to grow in line with the company's continued development, this is due to the cause of the tax rate. This means that there will be a reduction in the company's income because of the amount of tax paid, due to the impact of the use of large debt as well. In this study using the dependent variable is the capital structure and asset structure variables, profitability variables, firm size variables, and company growth variables are used as independent variables. And also using the control variable is the age of the company. In this study can be summarized in the hypothesis:

H1: The asset structure has a positive effect on DER
In capital structure theory it is said that there is a positive relationship between the amount of debt and tangible assets owned. This tangible asset is one of the wealth of a company that has very many benefits. Tangible assets that are large in number owned by the company will have a large guarantee of the loan funds received. Investors will categorize borrowing companies with creditor status with low risk or low risk. This will make it easier to get loan funds. Besides that, high liquidity values are also taken into consideration by investors in issuing loan funds, because if a creditors company is liquidated, the invested funds will be easily withdrawn through the assets.

The results of research by Indrajaya, Herlina, and Setiadi (2011) stated that a significant positive effect was shown by the structure of assets in their capital composition. This is in line with Yurian Ajie's research (2016). From the description above, it can be concluded that the company will use leverage to fulfill the source of funds if a company has a large number of fixed assets. So that the asset structure is positively correlated to the composition of the capital structure.

\section{H2: Return on Equity (ROA) has a positive effect on DER}

Companies tend to like internal funding or the use of their own funds if you look at the pecking order theory. The level of increase in company profitability will certainly increase the amount of money generated and certainly will increase the ability to fund the company's capital funding needs from its own funds. Likewise, the small profitability of a company will make it difficult for the company to fund itself from internal sources, so the first choice to invest is with external sources of funds. 
Some research results show the results of the effect of profitability on the capital structure. Indrajaya's research, Herlina, Rini, and Setiadi (2011) said the positive influence was shown by profitability on the composition of a company's funding. Likewise with the results of Nadzirah \& Cipta (2016) and Mahfuzah Salim \& Dr. Raj Yadav (2012) said there was a positive influence shown by profitability.

H3: Firm size has a positive effect on DER

Company assets can reflect the size or size of assets owned by the company. The method of measurement is seen from the total value of the assets it has. In a giant company, the amount of all assets can be seen with certainty so that the risk of corporate bankruptcy is unlikely. Funding needs for large companies are also in line with their large size because of the extensive operational components that require large funds. Investor confidence in large companies is certainly credible. Companies like this will spread positive signals to investors to invest.

Some research results mostly show that positive influence is indicated by the size of the company, as well as research by Acaravci (2015), Indrajaya, Herlina, and Setiadi (2011), Argi Alvareza (2017), Seftianne (2011), Yurian Ajie (2016), and Devi Esa Putri (2016).

\section{H4: Company growth has a positive effect on DER}

The company's growth is a reference that can be used as a benchmark for the success of a company. The main purpose of doing business is, of course, to continue to grow the company, both in terms of assets, profits earned, market share and the growth of the product variants that become the business. The easiest thing to see the growth rate of a company is to know the number of assets it has. As a result of large profits, the amount of retained earnings that will be used for company expansion will also increase. This will automatically increase the number of assets owned. With an increase in the amount of internal capital, it is assumed that the company's funding needs from external sources or debt funds will be relatively fixed or even smaller, which will lead to a decrease in the debt-equity ratio (DER).

Even so, several studies such as the results of Acaravci's (2015) study said that positively influencing is the growth of the company. Likewise with the results of research by Indrajaya, Herlin, and Setiadi (2011) which stated the same thing too. Similarly, the results of Argi Alvareza's (2017) research also stated that having a positive influence was the company's growth rate.

\section{METHOD}

The data used is quantitative data. Whereas if it is seen from the method of obtaining it, namely obtaining it indirectly, the data used is secondary data obtained from published annual reports in the Indonesian Capital March Directory (ICMD) manufacturing companies that have been listed on the Indonesia Stock Exchange (IDX). Where to use 2013 to 2017 as the year of research.

\section{Population and Sample}

Companies in the manufacturing sector that are listed on the IDX are used as populations. Whereas for the data collection period starting from 2013 to 2017. To fulfill the purpose of this study the method used to take while using the purposive sampling method is the restriction on sampling with special rules, namely: (a) Manufacturing companies listed on the IDX; (b) Already registered on the IDX for the period 2013 to 2017; (c) The 
company publishes a complete and published Performance Report or Financial Report starting from the Income Statement, Balance Sheet from 2013 to 2017; (d) The published Performance Report or Financial Report experiences profits during the period 2013 to 2017; (e) The issued shares remain active until the period of December 31, 2017. From those conditions, there were 52 companies, according to Table 1 ,
Multiple Regression Analysis is the technique used in this study. Where the dependent variable is used is the capital structure (Y) and the independent variables are asset structure variables (X1), profitability variables (X2), firm size variables (X3), company growth variables (X4).

\section{Table 1}

Research Sample Selection

\begin{tabular}{clcc}
\hline No & \multicolumn{1}{c}{\begin{tabular}{c}
\multicolumn{1}{c}{ Information } \\
\multicolumn{1}{c}{ Population }
\end{tabular}} & $\begin{array}{c}\text { Number of } \\
\text { Companies }\end{array}$ & The Rest \\
\hline \multicolumn{1}{c}{$\begin{array}{l}\text { Manufacturing companies listed on the Indonesia Stock } \\
\text { Exchange (IDX) }\end{array}$} & 144 & 144 \\
\hline 2 & $\begin{array}{l}\text { Not listed on the Indonesia Stock Exchange (IDX) from 2013 to } \\
2017\end{array}$ & 16 & 128 \\
\hline 3 & The company publishes incomplete financial statements & 13 & 115 \\
\hline 4 & $\begin{array}{l}\text { The company's financial statements suffered losses during } \\
2013-2017\end{array}$ & 54 & 61 \\
\hline 5 & $\begin{array}{l}\text { Shares of companies that are inactive are operating until } \\
\text { December 31, 2017 }\end{array}$ & 9 & 52 \\
\hline & $\quad$ Number of Samples & \multicolumn{2}{c}{$\mathbf{5 2}$} \\
\hline
\end{tabular}

\section{RESULT AND DISCUSSION}

The general description of the variables in this study is the results of descriptive analysis on the variables of this study consisting of the lowest value and the highest value, then the standard deviation and the average value. The variables in this study consisted of dependent variables namely capital structure (Y), and the dependent variable consisting of asset structure (X1), profitability (X2), firm size (X3) and company growth (X4), as well as one control variable, namely company age (X5). Descriptive statistics results like the following Table 2.

It can be seen in Table 2 above that there are 260 processed data and can be seen in column $\mathrm{N}$. This is obtained from the number of research samples that have been selected from a population of 144 manufacturing companies into 52 manufacturing companies, then from 52 company data taken from in 2013-2017 or as many as 5 years so that a lot of data is processed as much as 260 data.

That the average capital structure obtained is $0.942 \%$, the standard deviation is 0.905 , which means that the value is more than the standard deviation. This condition indicates that the fluctuations in the value of a small capital structure or the distribution of capital structure data are still around the average value. The table shows the lowest value is $0.08 \%$ while the highest is $7.4 \%$, with an average of $0.942 \%$, so it can be said that many values above the average or most manufacturing companies that are sampled use debt as a financing approach. 
Table 2 shows that the average asset structure is $0.452 \%$, the standard deviation is 0.667 , which means that the average value is less than the standard deviation. This condition indicates that the fluctuations in the value of the structure of a large asset or the spread of the structure data of the spread assets or not around the average value. The figures in table 2 also note that the lowest value is $0.00 \%$ and the highest value is $6.97 \%$, with an average of $0.452 \%$ so it can be said that many values are below average or most manufacturing companies are asset samples still owned is still below average.

Table 2 shows the average value of profitability of $20.823 \%$, standard deviation with a value of 151.3388 , meaning that the value is less than the standard deviation. This condition shows that a large fluctuation in profitability value or the distribution of profitability data is still around its average value. From the table it can be seen that the lowest value is $0.05 \%$ and the highest value is $2125.00 \%$, with an average of $20.825 \%$, it can be said that many values above the average or most manufacturing companies that are sampled use profit the above average.

Company size is the number of company assets. Table 2 also shows the average value of the company size 14,814 , the standard deviation is 1,896 , meaning that the average is more than the standard deviation. This condition indicates that the fluctuations in the value of small company size or the distribution of company size data are still around the average value. From the table above also found that the lowest value is 9.98 and the highest value is
19.5 , with an average of 14.814 , it can be said that many values that are below average or most manufacturing companies that are sampled have a company size that is still below average.

The company's growth is a percentage increase in assets from year to year. Table 2 also produces an average number of 4,282 for company growth, a standard deviation of 63,801 , it can be said that the average value is less than the standard deviation. This means a large value fluctuation in the company's growth and in other words that the data obtained is not spread around its average value. From the table above it is found that the lowest value is -1.00 and the highest value is 1028.73 , with an average of 4.282 , it can be said that many values above the average or most of the manufacturing companies that become samples have a value of growth above average.

Age is the length of time a company stands measured since the company is actively listed on the Indonesia Stock Exchange. The table above shows the average of 20.52 for the age of the company, the standard deviation is 7.288, meaning that the average is more than the standard deviation. This condition indicates that fluctuations in the age value of a small company or the distribution of company age data are still around its average value. From the table above it is found that the lowest value is 1 and the highest value is 35 , with an average of 25.52 so it can be said that many values above the average or most manufacturing companies that become samples have an age that is still below average. 
Table 2

Results of Descriptive Statistical Analysis Data of Research Sample Variable Descriptive Statistics

\begin{tabular}{l|c|r|r|r|r}
\hline & N & Minimum & Maximum & Mean & Std. Deviation \\
\hline Capital Structure & 260 &, 08 & 7,40 &, 9422 &, 90485 \\
\hline Aktiva Structure & 260 &, 03 & 697,21 & 45,1664 & 66,76037 \\
\hline Profitability & 260 &, 05 & 2125,00 & 20,8228 & 151,38855 \\
\hline Size Companies & 260 & 9,88 & 19,50 & 14,8136 & 1,89652 \\
\hline Company Growth & 260 & $-99,90$ & 102872,95 & 428,2206 & 6380,12653 \\
\hline Age & 260 & 1 & 35 & 20,52 & 7,288 \\
\hline Valid N (listwise) & 260 & & & & \\
\hline
\end{tabular}

Before the classical assumption test is carried out, first testing of the company's age variable can be used as a control variable or not. To find out this, a simple regression test between the firm's age

Table 3

Statistical Test Results t Age Variables as Control Variables

\begin{tabular}{|c|c|c|c|c|c|}
\hline \multirow[b]{2}{*}{ Model } & \multicolumn{2}{|c|}{$\begin{array}{l}\text { Unstandardized } \\
\text { Coefficients }\end{array}$} & \multirow{2}{*}{$\begin{array}{c}\text { Standardized } \\
\text { Coefficients } \\
\text { Beta }\end{array}$} & \multirow[b]{2}{*}{$\mathrm{t}$} & \multirow[b]{2}{*}{ Sig. } \\
\hline & B & Std. Error & & & \\
\hline 1 (Constant) & $-1,173$ & ,538 & & $-2,180$ & 031 \\
\hline Age & -028 & 081, & -024 &,- 350 & 727, \\
\hline
\end{tabular}

Figure 1

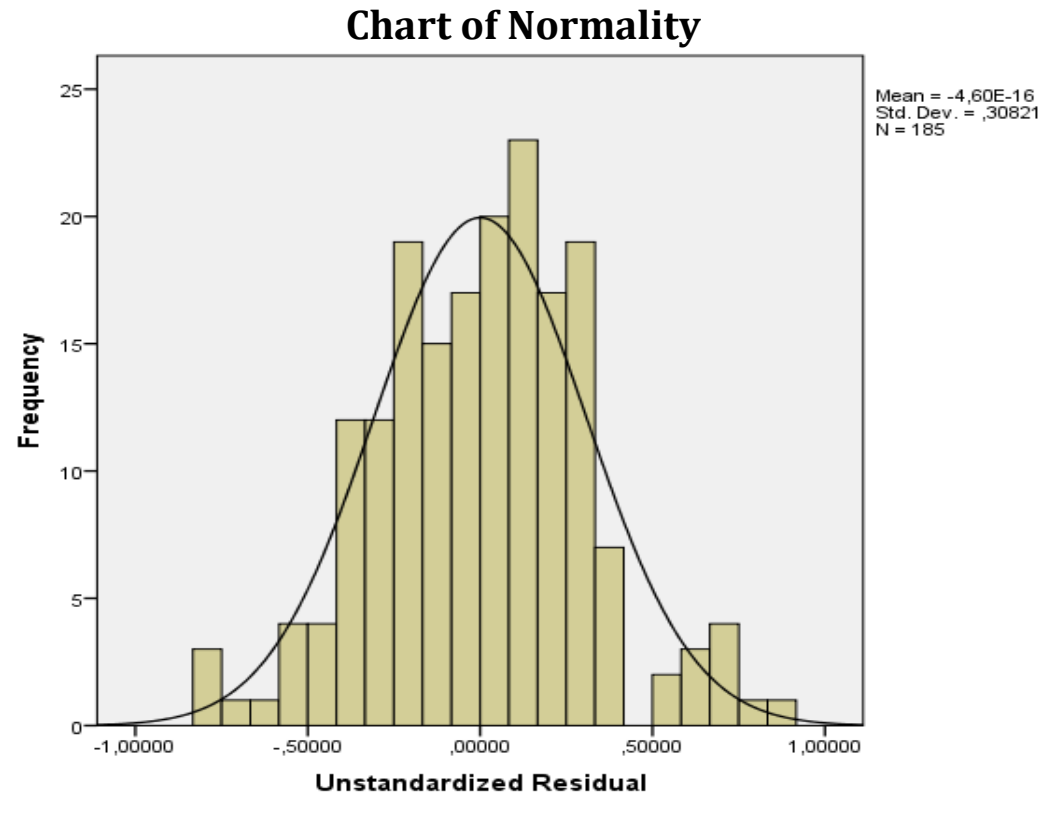


Table 3 describes that it is found that the regression coefficient value at the company age variable is negative 0.028 with a significant value of the age of the company having a value of 0.727 so that it is more than 0.05 . It can be said that the company age variable as a control variable partially does not affect the capital structure. So that the age of the company cannot be used as a control variable. From Figure 1 it can be seen that the histogram graph has a curved pattern in the middle or does not look right or left. This indicates that the sample data is normally distributed.

\section{Table 4}

Kolmogrof-Smirnov (K-S) Test Results

One-Sample Kolmogorov-Smirnov Test

\begin{tabular}{lrr}
\hline & & $\begin{array}{c}\text { Unstandardized } \\
\text { Residual }\end{array}$ \\
\hline $\mathrm{N}$ &, 0000000 & 186 \\
\hline Normal Parameters ${ }^{\mathrm{a}, \mathrm{b}}$ &, 30754138 &, 0000000 \\
\cline { 2 - 3 } &, 050820760 \\
\hline Most Extreme Differences &, 055 &, 056 \\
\cline { 2 - 3 } &,- 033 &, 056 \\
\hline Test Statistic & &,- 033 \\
\hline Asymp. Sig. (2-tailed) & &, 055 \\
\hline
\end{tabular}

a. Test distribution is Normal.

b. Calculated from data.

c. Lilliefors Significance Correction.

d. This is a lower bound of the true significance.

Table 5

Multikolinierity Test Result

\begin{tabular}{llr|r}
\hline \multirow{2}{*}{ Model } & & \multicolumn{2}{c}{ Collinearity Statistics } \\
\cline { 3 - 4 } 1 & (Constant) & Tolerance & \multicolumn{1}{c}{ VIF } \\
\cline { 2 - 4 } & Aktiva Structure &, 941 & 1,062 \\
\cline { 2 - 4 } & Profitability &, 946 & 1,057 \\
\cline { 2 - 4 } & Company Size &, 956 & 1,046 \\
\cline { 2 - 4 } & Company Growth &, 953 & 1,049 \\
\hline
\end{tabular}

Table 6

Durbin Watson Results Test

Model Summary ${ }^{b}$

\begin{tabular}{|c|c|c|c|c|c|}
\hline Model & $\mathrm{R}$ & R Square & $\begin{array}{l}\text { Adjusted R } \\
\text { Square }\end{array}$ & $\begin{array}{l}\text { Std. The error of } \\
\text { the Estimate }\end{array}$ & Durbin-Watson \\
\hline 1 &, $445^{a}$ & , 198 & ,180 & ,31092 & 1,966 \\
\hline
\end{tabular}

a. Predictors: (Constant), Pertumbuhan Perusahaan, Profitabilitas, Ukuran Perusahaan, Struktur Aktiva

b. Dependent Variable: Struktur Modal 
In Table 4 can be seen that the significance value obtained is equal to 0.200 more than 0.05 . The assumption of normality is fulfilled or it can be concluded that the residual data is normally distributed because the value shown is significantly more than the number 0.05 .

Based on Table 5 , it can be seen that all tolerance values are more than 0.01 or none less than 0.01 and all VIF values are less than 10 or no value exceeds 10 . Meaning that all independent variables do not occur multicollinearity between variables in the regression model.

Based on Table 6, it can be seen that the results of the Durbin-Watson (DW) value are 1.959. Because $-2 \leq \mathrm{DW} \leq 2$, it is in an area that states that autocorrelation does not occur. So there is no autocorrelation in the regression model.

\section{Figure 2}

\section{Heteroscedasticity Plot Diagram}

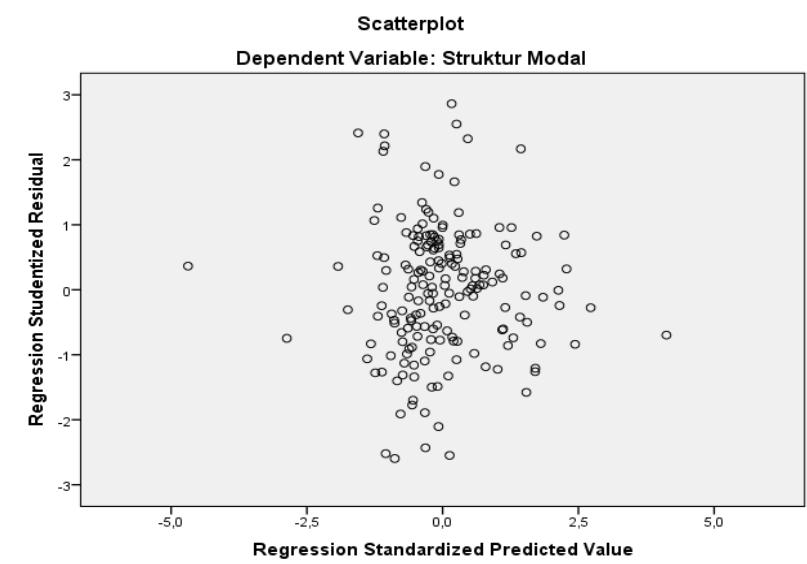

Table 7

F Test Results

ANOVA $^{\mathrm{a}}$

\begin{tabular}{|c|c|c|c|c|c|}
\hline Model & $\begin{array}{c}\text { Sum of } \\
\text { Squares }\end{array}$ & df & Mean Square & $\mathrm{F}$ & Sig. \\
\hline 1 Regression & 4,316 & 4 & 1,079 & 11,161 &, $000^{\mathrm{b}}$ \\
\hline Residual & 17,498 & 181 & ,097 & & \\
\hline Total & 21,814 & 185 & & & \\
\hline
\end{tabular}

a. Dependent Variable: Struktur Modal

b. Predictors: (Constant), Company Growth, Profitability, Company Size, Activa Structure

Table 8

Statistics t-Test Result

\begin{tabular}{|c|c|c|c|c|c|}
\hline \multirow[b]{2}{*}{ Model } & \multicolumn{2}{|c|}{ Unstandardized Coefficients } & \multirow{2}{*}{$\begin{array}{c}\text { Standardized } \\
\text { Coefficients } \\
\text { Beta }\end{array}$} & \multirow[b]{2}{*}{$\mathrm{t}$} & \multirow[b]{2}{*}{ Sig. } \\
\hline & B & Std. Error & & & \\
\hline 1 (Constant) & $-1,182$ & ,536 & & $-2,204$ & ,029 \\
\hline Aktiva Structure & 073 & ,085 & , 059 & ,854 & ,394 \\
\hline Profitability &,- 272 & 047 &,- 398 & $-5,812$ & 000 \\
\hline Company Size & ,980 & ,424 & ,158 & 2,314 & 022 \\
\hline Company Growth &,- 032 & ,036 &,- 061 &,- 902 & ,368 \\
\hline
\end{tabular}


In Figure 2, it can be seen that the plot diagram shows the distribution around zero, some are above and below the zero lines but there are no specific images. So there is no heteroscedasticity. Table 7 shows a significant 0.00 . Means that for all independent variables the dependent variable has an effect. This occurs because the significant value does not exceed 0.05 . Furthermore, the t-test will be carried out on independent variables but measured individually. In table 8 can be known as the regression equation by looking at the value of each variable in column $B$, namely:

$$
\begin{aligned}
\text { Capital Structure } & =-1,182+0.73 \text { Asset Structure } \\
& -0.272 \text { Profitability } \\
& +0.980 \text { Company Size } \\
& -0.32 \text { Company Growth }
\end{aligned}
$$

The results above can be interpreted as follows:

1. Constants of -1.182 state that if all independent variables (asset structure, firm size, profitability and company growth) are 0 (zero) then the dependent value (capital structure) is 1.182.

2. The regression coefficient on the asset structure variable is positive 0.73 with the significant value of the asset structure having a value of 0.394 so that it is more than 0.05 . This shows that partially the asset structure variable has no significant effect. So it can be concluded that partially asset structure variables have a positive but not significant effect on capital structure variables.

3. The regression coefficient on profitability variables is negative 0.272 with a significant value of profitability having a value of 0.000 so that it is less than 0.05. This shows that partially the profitability variable has a significant effect. So it can be concluded that partially the profitability variable has a negative and significant effect on capital structure variables.

4. The regression coefficient on the firm size variable is positive at 0.980 with the significant value of the firm size having a value of 0.022 , which means it is smaller than 0.05 . This means that the size of the company has significant influence and has a positive influence.

5. Regression coefficient on the company's growth variable is negative 0.032 with a significant value of company growth has a value of 0.368 , so it is smaller than 0.05 . This means that the growth of the company does not have a significant influence. So that it can be concluded that partially variable to capital structure variables.

\begin{tabular}{|c|c|c|c|c|c|}
\hline Model & $\mathrm{R}$ & R Square & Adjusted R Square & $\begin{array}{c}\text { Std. The error of the } \\
\text { Estimate }\end{array}$ & Durbin-Watson \\
\hline 1 & $445^{\mathrm{a}}$ & 198 & 180 & ,31092 & 1,966 \\
\hline
\end{tabular}

\section{Table 9}

\section{Determination Coefficient} Model Summary ${ }^{b}$

In table 9 can be seen that the value of Adjusted R Square $\left(\mathrm{R}^{\wedge} 2\right)$ is 0.180 or $18 \%$. This means that the composition of the independent variable has an influence of
$18 \%$ and the remaining $82 \%$ is influenced other than the variables studied. 


\section{Discussion of the effect of asset structure on capital structure}

H1 states that the capital structure is positively influenced by the asset structure. The results of the data analysis showed that partially the asset structure variables had a positive but not significant effect on capital structure variables. So that the first hypothesis (H1) in this study is not proven.

These results indicate that even though together with other variables will have a potential effect on the capital structure, but partially the structure of assets has no influence.

Discussion of the effect of profitability on capital structure

The second hypothesis (H2) states that profitability has a positive effect on capital structure. The results of the data analysis showed that partially the profitability variable had a negative and significant effect on capital structure variables. So the second hypothesis (H2) in this study is rejected.

This means that if the profitability is greater then the value of the capital structure gets smaller or in other words will reduce the company's debt as a source of funding. This is because companies with high-profit levels allow a company to be more independent in financing to meet the needs of the company itself. These results are in accordance with the results of the research conducted by Indrajaya, Herlina, and Setiadi (2011), namely the capital structure are negatively and significantly affected by profitability, this is in accordance with the study by Nadzirah and Cipta (2016) and Mahfuzah Salim researchers and Dr. Raj Yadav (2012). Thus a company needs to think of ways to have high profitability so that the company can reduce the debt burden.

\section{Discussion of the effect of firm size on capital structure}

The third hypothesis (H3) suggests that capital structure is positively influenced by firm size. From the results of the data obtained, it was found that the size of the company was positive and significantly affected. So that the third hypothesis (H3) in this research is proven. These results are consistent with the results of research conducted by Acaravci (2015), Indrajaya, Herlina, and Setiadi (2011), Argi Alvareza (2017), Seftianne (2011), Yurian Ajie (2016), and Devi Esa Putri (2016). The greater the debt as a source of funding, this is likely to occur because a large company will guarantee more access to get the funds. So it will be easier to get debt.

Discussion of the Influence of Company Growth on Capital Structure

The fourth hypothesis (H4) says that capital structure is positively influenced. From the data analysis concluded that the capital structure is negatively and insignificantly affected. The hypothesis in this study is not proven. Research that says the same thing is by Putu Hary and I Gusti Bagus (2015).

\section{CONCLUSION AND SUGGESTION}

The results of the data analysis described in the chapters above, namely to determine the effect that occurs in the composition of the capital structure on the variables under study, so with this conclusion produced:

1. Based on the results of data analysis shows that the regression coefficient on the asset structure variable is positive 0.70 with a significance value of 0.412 so that it has a positive and insignificant effect. Hypothesis 1 was rejected because the results of the study did not show any influence.

2. Based on the results of data analysis shows that the regression coefficient on the profitability variable is negative 
0.272 and also has a value of 0.000 for the significance value. So it can be concluded that it has a significant negative effect. So that hypothesis 2 is not proven and shows that the high profit obtained by the company will make the company use more internal funding sources, thereby reducing the use of corporate debt.

3. The results of data analysis showed that the regression coefficient on the firm size variable was positive 0.968 with a significant value of 0.024 , so it has a positive and significant influence. Thus H3 states that capital structure is positively influenced.

4. Based on the results of data analysis showed that the regression coefficient on the company's growth variable was negative 0.034 with a significant value of 0.364 so that the negative but not significant effect.

\section{Suggestion}

The research that the author did also reinforce the results of previous studies namely:

1. The profitability variable has a negative influence on the capital structure composition variable. The results of this study support the results of research conducted by Acaravci (2015),
Ganguli (2013), Ida Bagus \& Made Rusmala (2015), and Devi EsaPutri (2016), but contrary to the results of research conducted by Indrajaya, Herlina, and Setiadi (2011), Nadzirah and Cipta (2016), and Mahfuzah Salim and Dr. Raj Yadav (2012) states that profitability has a positive effect on the capital structure, as well as research that has been carried out by Argi Alvareza (2017), Seftianne (2011), and Yurian (2016) which states that profitability does not affect the capital structure.

2. Capital structure is influenced by the size of the company. This study supports the results of studies by Acaravci (2015), Indrajaya, Herlina, and Setiadi (2011), Argi Alvareza (2017), Seftianne (2011), Yurian (2016), and Devi EsaPutri (2016), but contrary to the results of the study what has been done by Mahfuzah Salim \& Dr. Raj Yadav (2012) which produces a capital structure is negatively affected by the size of the company, and in line with the study of Ida Bagus \& Made Rusmala (2015) which states that the size of the company does not affect the capital structure.

\section{REFERENCES}

Ali Kesuma. 2009. Analisis Faktor yang Mempengaruhi Struktur Modal Serta Pengaruhnya Terhadap Harga Saham Perusahaan. Jurnal Manajemen \& Kewirausahaan, vol. 11, no. 1.

Farah Margaretha dan Aditya Rizky Ramadhan. 2010. Faktor -Faktor yang Mempengaruhi Struktur Modal pada Industri Manufaktur di Bursa Efek Jakarta. Jurnal Bisnis dan Akuntansi, vol. 12, no. 2.

Fatemeh Baghiyan. 2013. The Impact of Working Capital Management on Management Performance. Journal of Behavioral Economics, Finance, Entrepreneurship, Accounting and Transport, vol. 1, no. 1. 
Hadianto. 2008. Pengaruh Struktur Aktiva, Ukuran Perusahaan dan Profitabilitas Terhadap Struktur Modal Emiten Sektor Telekomunikasi Indonesia. Jurnal Management, vol. 7, no. 2.

Hamam Roni, Atim Djazuli, dan Djumahir. 2018. The Effect of Working Capital, Management On Profitability of State-Owned Enterprise In Processing Industry Sector. Jurnal Aplikasi Manajemen, vol. 16, no. 2.

Hendri Setyawan \& Sutapa. 2006. Analisis Fakor Penentu Struktur Modal. Jurnal Akuntansi dan Keuangan, vol. 5, no. 2.

Mustafa Afeef. 2011. Analyzing the Impact of Working Capital Management on The Profitability of SME's in Pakistan. International Journal of Business and Social Science, vol. 2, no. 22.

Kartini, Tulus Arianto. 2008. Struktur Kepemilikan, Profitabilitas, Pertumbuhan Aktiva dan Ukuran Perusahaan Terhadap Struktur Modal pada Perusahaan Manufaktur. Jurnal Keuangan dan Perbankan, vol. 12, no. 1.

Lukman Purnomosidi, Suhadak, Hermanto Siregar, dan M Dzulkirom. 2014. The Influences of Company Size, Capital Structure, Good Corporate Governance, Inflation, Interest Rate, and Exchange Rate of Financial, Performance and Value of The Company. Interdisciplinary Journal of Contemporary Research In Business, vol. 5, no. 10.

Maharani Retnaningrum. 2012. Faktor - Faktor yang Mempengaruhi Struktur Modal Emiten Sektor Manufaktur di BEI. Jurnal Bisnis Strategi, vol. 21, no. 2.

Mias Fatimatuzzahra dan Retno Kusumastuti. 2016. Determinant of Working Capital Management of Manufacturing Companies. Mimbar, vol. 32, no. 2.

Mutamimah. 2003. Analisis Struktur Modal Pada Perusahaan - Perusahaan Non Financial yang Go Public di Pasar Modal Indonesia. Jurnal Keuangan, vol. 11, no. 8.

Riski Ayu Pratiwi Batubara, Topowijono, Zahroh ZA. 2017. Pengaruh Struktur Aktiva, Ukuran Perusahaan, dan Profitabilitas Terhadap Struktur Modal. Jurnal Administrasi Bisnis, vol. 50, no. 4.

Saidi. 2004. Faktor - Faktor Yang Mempengaruhi Struktur Modal pada Perusahaan Manufaktur Go Public di BEJ. Jurnal Bisnis dan Ekonomi, vol. 11, no. 1.

Seftianne. 2011. Faktor - Faktor yang Mempengaruhi Struktur Modal pada Perusahaan Publik Sektor Manufaktur. Jurnal Bisnis dan Akuntansi, vol. 13, no. 1.

Sujoko dan Ugy Subiantoro. 2007. Pengaruh Struktur Kepemilikan Saham, Leverage, Faktor Intern dan Ekstern terhadap Nilai Perusahaan. Jurnal Management dan Kewirausahaan, vol. 9, no. 1.

Yuke Prabansari, dan Handri Kusuma. 2005. Faktor - Faktor yang Mempengaruhi Struktur Modal Perusahaan Manufaktur Go Public di BEJ. Sinergi Kajian Bisnis dan Manajemen, Edisi Khusus on Finance, Hal. 1-15. 